\title{
Evaluation of Inappropriate Antibiotic Use in Pediatric Patients: Point-prevalence Study
}

\author{
Çocuk Hastalarda Uygunsuz Antibiyotik Kullanımının Değerlendirilmesi: \\ Nokta Prevalans Çalışması
}

\author{
Emine Hafize Erdeniz'(iD), Adem Dursun²(ID) \\ ${ }^{\prime}$ Department of Pediatric Infectious Diseases, Erzurum Regional Training and Research Hospital, Erzurum, Turkey \\ 2 Pediatric Intensive Care Unit, Erzurum Regional Training and Research Hospital, Erzurum, Turkey
}

Cite this article as: Erdeniz EH, Dursun A. Evaluation of inappropriate antibiotic use in pediatric patients: point-prevalence study. J Pediatr Inf 2020;14(2):e63-e68.

\begin{abstract}
Objective: Inappropriate antibiotic use leads to drug side effects, drug resistance and cost problems. This study aimed to analyze the rates and the reasons of antibiotic use and suitability of antibiotics.

Material and Methods: On the study day, pediatric patients hospitalized in Erzurum Regional Training and Research Hospital were evaluated for antibiotic use by using point prevalence study.

Results: It was observed that $79 \%$ of the 134 pediatric patients hospitalized on the study day received at least one antibiotic. Pulmonary infection was the most common cause of antibiotic use $(n=58,43 \%)$. The most commonly used antibiotic was ampicillin-sulbactam (29.9\%) and clarithromycin (24.6\%). The rate of inappropriate use was 39\%. When all inappropriate antibiotic users were evaluated, the most common reason for non-compliance was found as unnecessary multiple antibiotic use $(63.25 \%, n=27)$, followed by antibiotic use without antibiotic requirement $(16 \%, n=7)$, use of antibiotics with a spectrum broader than necessary $(14 \%, n=6)$, use of antibiotics with a spectrum narrower than necessary $(4.5 \%, n=2)$, and wrong dosage $(2 \%, n=1)$. All of the patients who received inappropriate antibiotics were treated empirically.
\end{abstract}

Conclusion: It is important to conduct periodic point prevalence studies in order to show possible problems related to antibiotic use.

Keywords: Antibiotic, inappropriate antibiotic use, point-prevalence study
Öz

Giriş: Uygunsuz antibiyotik kullanımı ilaç yan etkisi, ilaç direnci ve maliyet sorunlarına yol açmaktadır. Bu çalışmada antibiyotik kullanım oranları, nedenleri, antibiyotiklerin uygun kullanılıp kullanılmadığının analizinin yapılması amaçlanmıştır.

Gereç ve Yöntemler: Çalışma günü Erzurum Bölge Eğitim ve Araştırma Hastanesinde yatmakta olan çocuk hastalar antibiyotik kullanımı yönünden nokta prevalans yöntemi kullanılarak değerlendirildi.

Bulgular: Çalışma günü yatan 134 çocuk hastanın \%79'unun en az bir antibiyotik aldığı görülmüştür. Antibiyotik kullanma sebepleri arasında akciğer enfeksiyonu ilk sırayı almıştır ( $n=58, \% 43)$. En sık kullanılan antibiyotik \%29.9 ile ampisilin-sulbaktam, ikinci sıklıkta ise \%24.6 ile klaritromisin tespit edilmiştir. Uygunsuz kullanım oranı \%39 olarak bulunmuştur. Tüm uygunsuz antibiyotik kullanan hastalar değerlendirildiğinde en sık uygunsuzluk nedeni gereksiz çoğul antibiyotik kullanımı olmuştur (\%63.25, n= 27). Bunu sırasıyla antibiyotik gereksinimi olmadan antibiyotik kullanımı (\%16, $n=7)$, gereğinden geniş spektrumlu kullanım (\%14, $n=6)$, gereğinden dar spektrumlu kullanım $(\% 4.5, n=2)$ ve yanlış doz kullanımı $(\% 2, n=1)$ izlemiştir. Uygunsuz antibiyotik kullanan hastaların tamamına tedavi ampirik olarak başlanmıştır.

Sonuç: Belli aralıklarla nokta prevalans çalışmasının yapılması antibiyotik kullanımı ile ilgili olası sorunları göstermesi açısından önemlidir.

Anahtar Kelimeler: Antibiyotik, nokta prevalans çalışması, uygunsuz antibiyotik kullanımı 


\section{Introduction}

As in the world, antibiotics are the most frequently used drugs in our country. Rational antibiotic use is the planning, execution and observation process that ensures effective, safe and economic implementation of antibiotic treatment (1).

Unnecessary or inappropriate antibiotic use leads to an increase in antibiotic resistance and in pathogenic microorganisms like Clostridium difficile, and brings along treatment failures and negativities like rise in drug side-effects and treatment cost (2). Simple hand hygiene and appropriate antibiotic use have been found efficient in decreasing hospital-acquired infection (2). Hospital infections and antibiotic resistance can be lowered with multifaceted infection control and antibiotic management program (3). According to the 2013 report of US Centers for Disease Control and Prevention (CDC), it is estimated that two million infections resistant to antibiotics result in 23.000 deaths every year in the United States of America. Current data reveal that inappropriate antibiotic use is a serious health problem. Therefore, CDC recommends all hospitals to have an antibiotic management program in order to help reduce the start of inappropriate antibiotics until 2020 (4).

Using the point-prevalence method, this study aimed at investigating whether the antibiotic use of pediatric patients hospitalized in Erzurum Regional Training and Research Hospital was appropriate or not in order to determine the frequency of inappropriate antibiotic use and draw attention to this matter.

\section{Materials and Methods}

\section{Data Collection}

Pediatric patients hospitalized in the pediatric ward, intensive care and surgical departments of Erzurum Regional Training and Research Hospital on February $12^{\text {th }}, 2019$ were evaluated for antibiotic use using the point-prevalence method.

Patients' demographics, departments, underlying diseases, infectious focus, laboratory values [white blood cell, C-reactive protein (CRP)], antibiotics used, dosage of the antibiotics, length and way of use (prophylactic, empirical towards the possible agent, according to culture result), and infectious diseases department consultation were recorded on the form prepared. The forms of the patients using antibiotics on the day of the study were filled out by basing on the information received form the physician and assessing nurse observations. The study was approved by the local ethics comitee of Erzurum Regional Training and Research Hospital (with a reference number of 2019/02-16).

Inappropriate antibiotic use was evaluated taking into account unnecessary antibiotic use, unnecessary multiple antibiotic use, antibiotic use at an inappropriate dosage, use of antibiotics with a broader spectrum than necessary, use of antibiotics with a narrower spectrum than necessary, and prolonged prophylaxis and considering the basic principles of antibiotic use and antimicrobial treatment guidelines by the pediatric infectious diseases' specialist.

\section{Statistical Analysis}

SPSS version 21.0 (IBM Corp.; Armonk, NY, USA) program was used for statistical analyses. Frequency data were expressed as (\%) number. Non-parametric data were expressed and median. Chi-square test was used to compare categoric data. $p<0.05$ was considered statistically significant for all data.

\section{Results}

The study included 134 patients with a median age of 14.5 months (4.8-42 months). Seventy-three (54.5\%) patients were males and 61 (45.5\%) were females. Sixty-six (49.3\%) patients were followed in the general pediatric ward, 14 (10.4\%) in pediatric subspecialty wards, $26(19.4 \%)$ in the pediatric intensive care, $28(20.9 \%)$ in surgical departments (pediatric surgery= 10 , cardiovascular surgery $=2$, burn unit $=11$, orthopedics $=2$, neurosurgery $=3$ ).

Seventy-nine percent of the patients were detected to be using antibiotics on the day of the study. A total of 204 antibiotics was given to 105 patients using antibiotics. While the first cause of antibiotic use was pulmonary infection $(n=58$, $43 \%$ ), it was followed by antibiotic use for surgical prophylaxis $(n=11,8.2 \%)$. Consultation from the infectious diseases clinic was received for $12 \%(n=13)$ of the patients using antibiotics. Median white blood cell count, median CRP, and median neutrophil percentage of the patients using antibiotics were found respectively as 10900 (8500-12350)/mm $\mathrm{mm}^{3}, 5.16$ (3.3$35.5) \mathrm{mg} / \mathrm{L}$, and $45 \%$ (29-74). An increase suggesting bacterial infection was detected in the CRP values of $20 \%$ of the patients using antibiotics.

The most frequently used antibiotic with a rate of $29.9 \%$ was ampicillin-sulbactam, followed by clarithromycin with a rate of $24.6 \%$. These were followed respectively by oseltamivir (20\%), ceftriaxone (15\%), meropenem (9\%), piperacillin-tazobactam (9\%), amikacin (9\%), teicoplanin (6.7\%), cefotaxime $(6 \%)$, metronidazole $(5.2 \%)$, cefazolin $(4.5 \%)$, vancomycin (3.7\%), ampicillin (2.2\%), clindamycin (1.5\%), linezolid (1.5\%), micafungin (1.5\%), fluconazole $(1.5 \%)$, cefotaxime $(0.7 \%)$, and gentamicin $(0.7 \%)$ (Figure 1$)$. Seventy-eight percent $(n=82)$ of the antibiotics used were started empirically, $13.3 \%(n=14)$ were agent-specific, and $8.5 \%(n=9)$ were prophylactic. The antibiotic most commonly started for empirical treatment was ampicillin-sulbactam (45.1\%), followed by clarithromycin (40\%) and oseltamivir (30\%). The most commonly used antibiotic for prophylaxis was cefazoline (44\%). The most frequently 


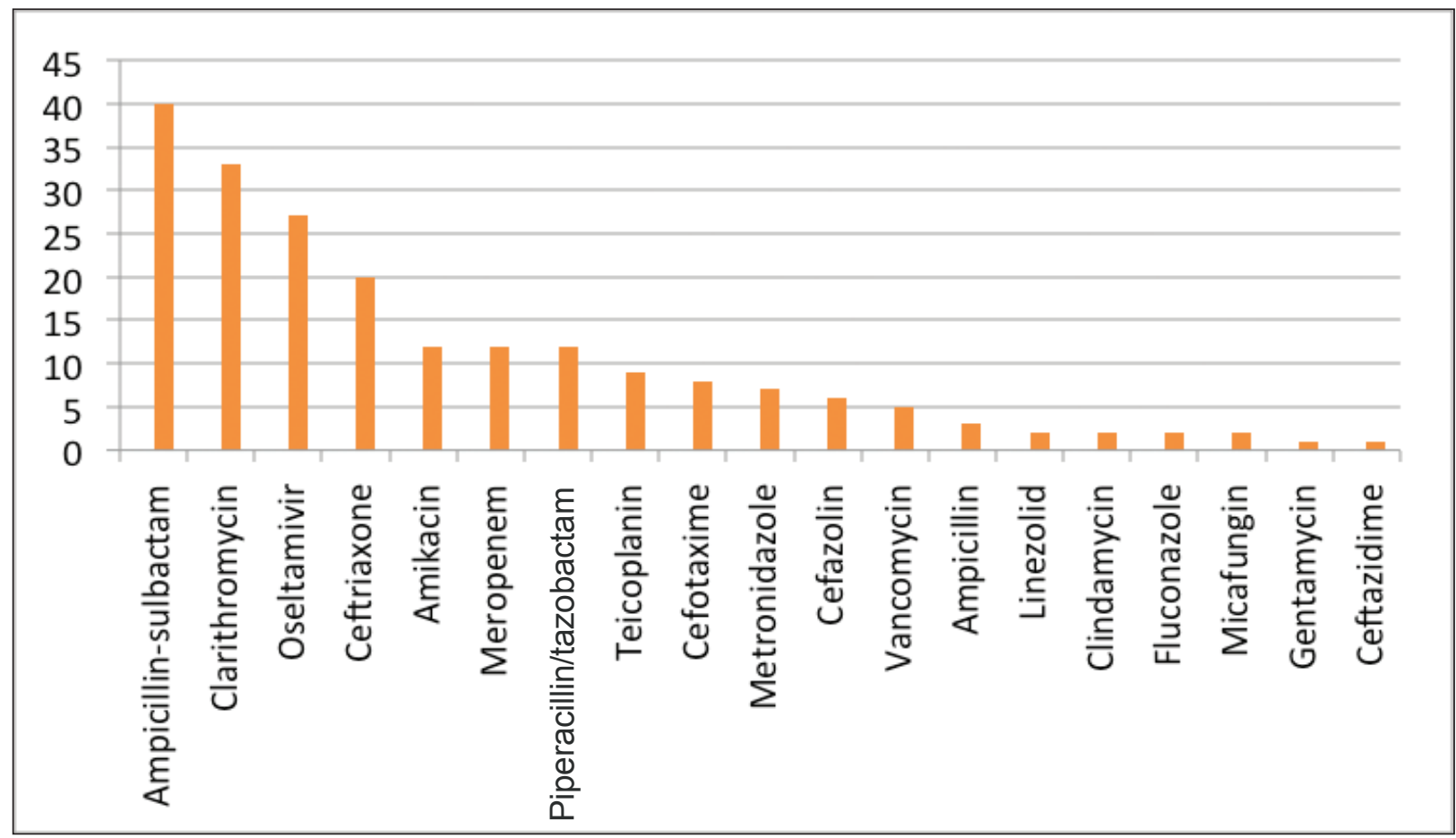

Figure 1. Antibiotics used in treatment and prophylaxis.

used antibiotic for agent-specific treatment was meropenem $(57.1 \%)$, followed by vancomycin (28\%) and amikacin (28\%). Pre-antibiotic culture was taken from $36.2 \%(n=38)$ of the patients using antibiotics. An agent was isolated in only $15.2 \%$ $(n=16)$ of the patients for whom antibiotics was started and culture was performed before antibiotic treatments.

Inappropriate antibiotic use was established as 39\% ( $\mathrm{n}=$ 44 ) in patients using antibiotics. When all patients using inappropriate antibiotics were evaluated, the most common cause for inappropriate use was multiple antibiotic use $(63.25 \%, n=$ 27), which was followed respectively by antibiotic use without the need for antibiotics $(16 \%, n=7)$, use of antibiotics with a broader spectrum than necessary $(14 \%, n=6)$, use of antibiotics with a narrower spectrum than necessary $(4.5 \%, n=2)$ and faulty dosage $(2 \%, n=1)$. The treatment was started empirically in all patients using inappropriate antibiotics. Inappropriate antibiotic use was not determined in patients receiving agent-specific antibiotics. The most frequent inappropriate antibiotic use was found in patients hospitalized with the diagnosis of pneumonia $(77.3 \%, n=34)$, which was followed by bronchiolitis $(6.8 \%, n=3)$, and gastroenteritis $(4.5 \%, n=2)$.

The most frequently and inappropriately used antibiotic was ampicillin-sulbactam $(61.4 \%, n=27)$, followed by clarithromycin $(59.1 \%, \mathrm{n}=29)$ and oseltamivir $(52.3 \%, \mathrm{n}=23)$. The only antibiotic used at inappropriate dosage was cefotaxime. The most commonly used antibiotics in unnecessary multiple treatment were clarithromycin $(77.8 \%, n=21)$, ampicillin-sulbactam $(74.1 \%, n=20)$ and oseltamivir $(63 \%, n=17)$.
While inappropriate antibiotic use in patients receiving infectious diseases consultation was $6 \%(n=1)$, it was $37 \%(n=$ 44 ) in patients not receiving consultation. Rate of inappropriate antibiotic use was statistically significantly low in the antibiotics started by the infectious diseases' specialist $(p<0.001)$. When rate of antibiotic use was evaluated as regards wards, the pediatric ward was the ward with the most common antibiotic use $(95 \%, n=63)$ (Table 1), which was followed by surgical departments $(78 \%, n=22)$, pediatric subbranches $(50 \%$, $n=7)$, and pediatric intensive care $(\% 50, n=13)$.

While inappropriate antibiotic use was confirmed as $59.1 \%$ in the pediatric ward, $19.2 \%$ in pediatric intensive care, and 3\% in surgical departments, it was not detected in the pediatric subbranch ward (Table 2).

\section{Discussion}

At the present time, antibiotics are widely used in the treatment of hospital and community-acquired infections and in surgical prophylaxis. This condition results in many misapplications, drug side effects, drug resistance, and increase in treatment cost $(2,5)$. This study is one of the rare studies in our country conveying experience on inappropriate use of antibiotics in pediatric patients, which has recently become a serious health issue.

In point-prevalence studies conducted in our country on the issue of antibiotic use, rates that differ between $27 \%$ to $70.8 \%$ have been reported (6-11). When studies carried out worldwide are considered, while rate of start of antibiotic use 
Table 1. Evaluation of the patients according to wards

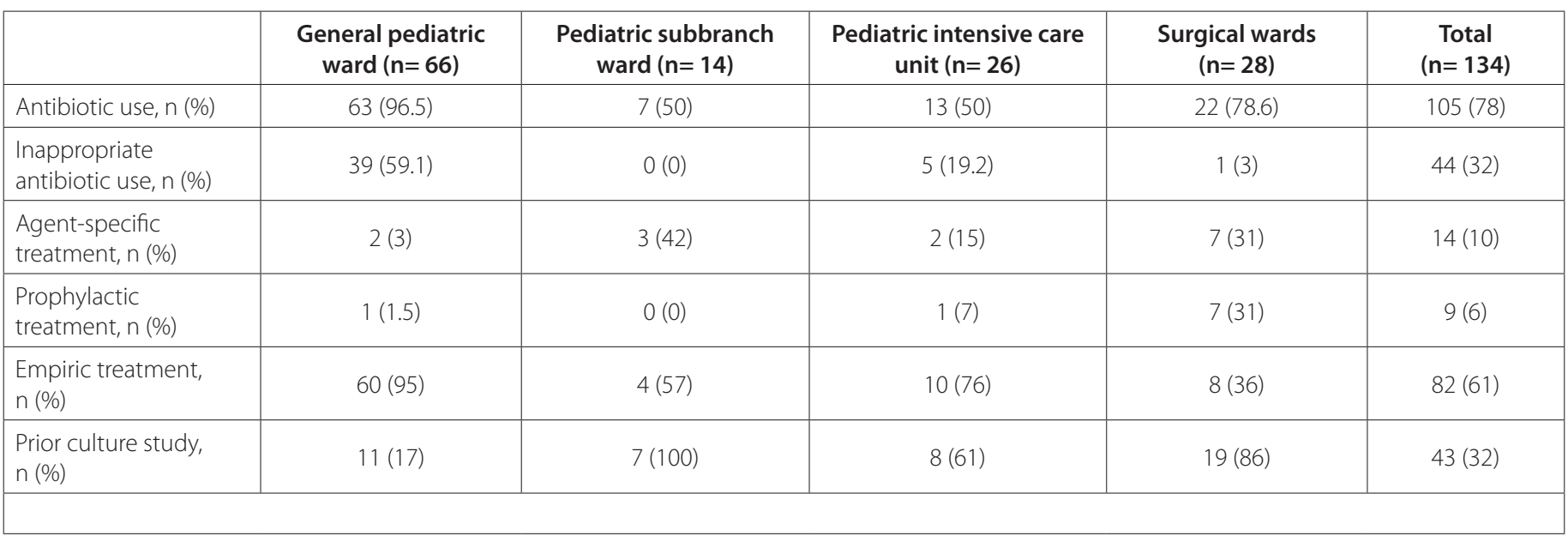

Table 2. Evaluation of the patients using inappropriate antibiotics according to wards

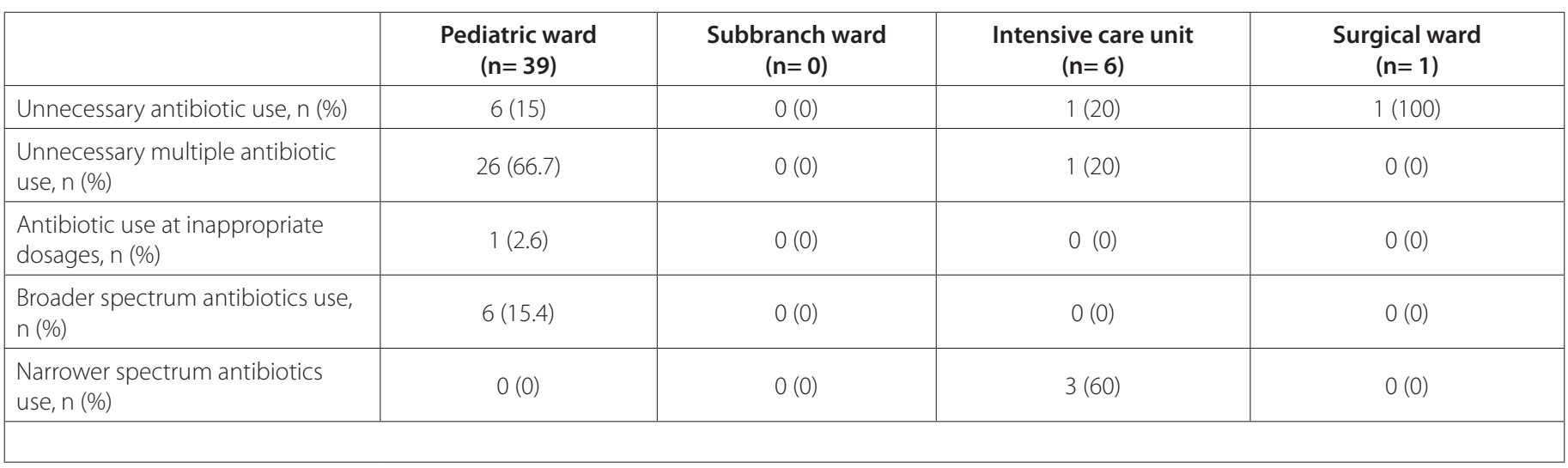

was detected $56 \%$ in a study from China including 13 hospitals, this rate was determined as significantly low as $32.6 \%$ in a prevalence study conducted between 2016 and 2017 in 28 European countries $(5,12)$. In our study, rate of start of antibiotic use in pediatric patients was found as $78 \%$. Our result was higher than that of the literature, which could be due to the fact that our hospital is a region hospital in Eastern Anatolia and we accept and follow clinically worse children from neighboring cities. Moreover, we are of the opinion that the high rate of antibiotic use found in our study may be related to the fact that the study was carried out during the Influenza season.

In a European surveillance study by Plachouras et al., including 310755 patients, it has been reported that the most common reason for the start of antibiotics was pneumonia and the most frequently started antibiotics were penicillin and a combination of beta-lactamase inhibitor (5). Similar results have been obtained by Ergül et al. in a study they conducted in our country on the matter (11). Our study also established in parallel to the condition in the world that the most com- mon reason for the start of antibiotics in patients was pneumonia and the most frequently consumed drug groups were penicillin and a combination of beta-lactamase inhibitor.

Rational antibiotic use consists of starting empirical treatment in patients with suspected or proven bacterial infection (i.e. before the presence of positive microbiological data) and arranging the use after receiving microbiological data. Empirical antibiotic selection is made by considering the severity of the disease, results of gram staining or rapid tests and regional antibiotic resistances (2). Unnecessary and inappropriate antibiotic use leads to side effect frequencies in patients, increase in antibacterial resistance, treatment failure, and thus a higher treatment cost. CDC estimates that $50 \%$ of all the antibiotics started are unnecessary or inappropriate (13). Ingram et al. have indicated that 199 out of the 462 (43\%) patients received antibiotic treatment and $47 \%$ of this antibiotic use was inappropriate in their prevalence study conducted in a tertiary hospital (14). In our country, Devrim et al. have reported inappropriate antibiotic use at a rate of $32.8 \%$ in their prevalence study performed on pediatric patients (10). Inappropriate an- 
tibiotic use was found as 39\% in our study. The results of our study were similar to those of the studies conducted in our country.

In the literature, the most common causes of inappropriate antibiotic use were prolonged prophylaxis and unnecessary use (5-11). The most common cause of inappropriateness was multiple antibiotic use, which was followed by antibiotic use without the need for antibiotics and antibiotic use with a broader spectrum than necessary. The treatment was started empirically in all patients using inappropriate antibiotics.

While starting antibiotics, patient's clinic and laboratory findings should be considered, the spectrum of the antibiotic started should not be broader or narrower than necessary, and unnecessary multiple treatment should be avoided. In our study, the most common antibiotic used inappropriately was ampicillin-sulbactam, followed by clarithromycin and oseltamivir. In the study by Ergül et al. on the inappropriate use of antibiotics, the most common antibiotic used inappropriately was ceftriaxone, the second was ampicillin-sulbactam (11). In the study by Devrim et al. the most common was sulbactam-ampicillin, followed by aminoglycosides and third generation cephalosporins (10).

It is known that consulting the infectious diseases department prior to the start of antibiotics improves antibiotic control policies $(11,12)$. Reporting that $9.8 \%$ of the antibiotics started prior to consultation to the infectious diseases department was terminated and that $57.4 \%$ of the treatments were modified has shown the importance of infectious diseases consultation by Yapar et al. (15). In our study, rate of inappropriate antibiotic use was found significantly low in patients for whom the pediatric infectious diseases consultation was carried out.

Rate of antibiotic use may differ from hospital to hospital and even from various clinics in the same hospital. In a multi-center study by Xiea et al. antibiotic use has been respectively reported as $90 \%$ and $39 \%$ in intensive care units and internal branches (12). In our country, Ergül et al. have found similar results, and antibiotic use has been determined respectively as $89 \%$ and $56 \%$ in pediatric intensive care unit and pediatric ward (11). Our study revealed that the rate of antibiotic use in the intensive care unit of our hospital was significantly lower than that of the literature. We are of the opinion that this is due to the pediatric palliative ward that diminishes the load of chronic patients and thus, decreases length of intensive care unit stay.

Rate of antibiotic use may differ in various months and seasons of the year. Determining this rate on one day in our study could be the limitation of our study by reflecting a particular moment rather than a process. We believe that sharing the feedbacks of periodically performed point-prevalence studies with the physicians in training meetings will be beneficial.

\section{Conclusion}

Inappropriate and unnecessary multiple antibiotic use is an important problem. Intermittent point-prevalence studies will be useful in showing possible problems regarding antibiotic use and the measures to be taken. Consulting an infectious diseases specialist may decrease the use of inappropriate antibiotics at a significant rate. In addition, chronic patient load can be reduced and length of intensive care unit stay can be shortened in hospitals by opening palliative wards, and thus antibiotic use can be significantly decreased.

Ethics Committe Approval: The study was approved by the local ethics comitee of Erzurum Regional Training and Research Hospital (with a reference number of 2019/02-16).

Informed Consent: Anonymous data were used for this study.

Peer-review: Externally peer-reviewed.

Author Contributions: Concept - EHE, AD; Design - EHE, AD; Supervision - EHE, AD; Data Collection and/or Processing - EHE, AD; Analysis and/or Interpretation - EHE, AD; Literature Review - EHE, AD; Writing - EHE, AD; Critical Review - EHE, AD.

Conflict of Interest: No conflict of interest was declared by the authors.

Financial Disclosure: The authors declared that this study has received no financial support.

\section{References}

1. Sürmelioğlu N, Kıroğlu O, Erdoğdu T, Karataş Y. Akılcı olmayan ilaç kullanımını önlemeye yönelik tedbirler. Arşiv Kaynak Tarama Dergisi 2015;24:452-62. [CrossRef]

2. Holubar M, Deresinski S. Antimicrobial stewardship in hospital settings. This topic last updated: Apr 02, 2019. [CrossRef]

3. Murni IK, Duke T, Kinney S, Daley AJ, Soenarto Y. Reducing hospital-acquired infections and improving the rational use of antibiotics in a developing country: an effectiveness study. Arch Dis Child 2015;100:4549. doi: 10.1136/archdischild-2014-307297. [CrossRef]

4. Centers for Disease Control and Prevention. Antibiotic/Antimicrobial Resistance (AR/AMR). https://www.cdc.gov/drugresistance/Accessed on September 10, 2018. [CrossRef]

5. Plachouras D, Karki T, Hansen S, Hopkins S, Lyytikainen O, Moro ML, et al.; The Point Prevalence Survey Study Group. Antimicrobial use in European acute care hospitals: results from these cond point prevalence survey (PPS) of healthcare-associated infections and antimicrobial use, 2016 to 2017. Euro Surveill 2018;23(47). doi: 10.2807/1560-7917. ES.23.46.1800393. [CrossRef]

6. Tartar AS, Denk A, Özden M, Kırık YÇ, Akbulut A, Demirdağ K. Fırat Üniversitesi Hastanesinde antibiyotik kullanımı uygunluğunun araştırılması: nokta prevalans çalışması. Ankem Derg 2015;29:16-20.

7. Inan A, Dağlı Ö, Akçay SŞ, Engin DÖ, Karagül E, Özyürek SÇ. Antibiotic use and cost in a teaching hospital in Istanbul. J Microbiol Infect Dis 2011;1(3):128-33. [CrossRef] 
8. Yılmaz G, Ozturk EM, Ayhan M, Coşkun B, Azap A. Bir üniversite hastanesindeki antibiyotik kullanımının araştırılması. Klimik Dergisi 2014;27(3):109-13. [CrossRef]

9. Saçar S, Kavas ST, Asan A, Cenger DH. Pamukkale Üniversitesi Tıp Fakültesi Hastanesinde antibiyotik kullanımına ilişkin nokta prevalans çalışması. ANKEM Derg 2006;20(4):217-21. [CrossRef]

10. Devrim I, Gülfidan G, Tavlı V, Dizdarer C, Yaşar N, Oruç Y, et al. Dr. Behçet Uz Çocuk Hastanesi'nde antibiyotik kullanımına ilişkin nokta prevalans çalışması. Çocuk Enf Derg 2009;3:11-3. [CrossRef]

11. Ergül AB, Gokcek I, Çelik T, Torun YA. Çocuk hastalarda uygunsuz antibiyotik kullanımının değerlendirilmesi: nokta prevalans çalışması. Turk Pediatri Ars 2018;53:17-23. doi: 10.5152/TurkPediatriArs.2018.5644. [CrossRef]
12. Xie $D S$, Xiang $L L, L i R, H u Q, L u o Q Q$, Xiong W. A multicenterpoint-prevalencesurvey of antibioticuse in 13 Chinese hospitals. J Infect Public Health 2015;8(1):55-61. [CrossRef]

13. Centers for Disease Control and Prevention. Antibiotic Resistance Threats in the United States, 2013. Atlanta, GA: Centers for Disease Control and Prevention; 2013. http://www.cdc.gov/drugresistance/ pdf/arthreats-2013-508.pdf. Accessed May 21, 2016. [CrossRef]

14. Ingram PR, Seet JM, Budgeon CA, Murray R. Point-prevalence study of inappropriate antibiotic use at a tertiary Australian hospital. Intern Med J 2012;42(6):719-21. doi: 10.1111/j.1445-5994.2012.02809.x. [CrossRef]

15. Yapar N, Erdenizmenli M, Oğuz VA, Kuruüzüm Z, Senger SS, Cakir N, et al. Infectious disease consultations and antibiotic usage in a Turkish university hospital. Int J Infect Dis 2006;10:61-5. [CrossRef] 